\title{
The Paradigm Role of ICT for Behavioral and Educational Psychology: The Case of Developing Countries
}

\author{
Gebeyehu Belay Gebremeskel, Ayenew Arega Kebede, and Yi Chai
}

\begin{abstract}
The purpose of this paper is to investigate the paradigm role of ICT for education as the case of learners and educator's behavioral and educational psychology's perspectives. I.e., ICT based education is an essential for new emerging information and then after knowledge societies, facilitating large-scale learning needs for social and economic development. The paper focused on ICT's applications and roles in education and the ICT's based learning process, competency, efficient use of a resource, developing innovative and novel ideas ... that could change and advance the learning environment and teaching practices. Since, evolution of the information society entails dramatic changes in production and business activities, as well as in a larger social context as digitized information or electronic networks, and also to understand in the broader context where bits, networks and knowledge have a social meaning. In general, the use of ICT in developing countries has many problems, and in this paper, we investigated some generic and pertinent issues on their educational systems and ICT involvements, which have aimed strongly at supporting the implementation of ICT in pedagogical practices at all institutional levels.
\end{abstract}

Index Terms-Behavioral psychology, education, ICT, learning process, modern system.

\section{INTRODUCTION}

Information Communication Technology (ICT) could be termed as educational technology in education industry. Semantically, it is the study and also ethical practice of facilitating, learning and improving performance by creating, using and managing appropriate technological processes and resources. Therefore, ICT for behavioral and educational psychology is simply referred to the use of modern technology, such as computers, digital technology, networked digital devices and associated software and courseware with learning scenarios, worksheets and interactive exercises that facilitate the learning process [1], [2] to create information society. The paradigm role of ICT is a profound change in teaching and learning practices, among both educational researchers and policy-makers. Distribution, use, and practices, as well as individuals' ICT skills change rapidly as new applications replace old ones, and new tools and applications come on the market every time. This has increased the use of ICT dramatically. Similarly, the access to ICT has improved among students and teachers, and both at home and at school.

Manuscript received September 1, 2014; revised November 13, 2014. Gebeyehu Belay Gebremeskel and Yi Chai are with Chongqing University College of Automation, China (e-mail: Gebeyehu@cqu.edu.cn, chaiyi@cqu.edu.cn)

Ayenew Arega Kebede is with Chongqing Mexin Property Management Co. Ltd., Chongqing, China (e-mail: ayenew.arega@yahoo.com).
Educational technology is an engine for development; resources use optimization and facilities, access and safety, and also future educational strategic plan. Thus, it is vitally important to learners and/or educators anytime and anywhere, business and other settings. The technology encompasses both educational and developmental material objects, such as machines and networking hardware, as well as theories such as instructional theory and learning facilities. ICT for education is an integral part of societies' everyday life, which refers to an array of tools and the principles for their effective application in learning process and facilities [3]. ICT for behavioral and educational psychology is therefore, methodologies and techniques, and skills assessment for learners and educators in their learning provider institutions towards its impacts. ICT as the paradigm of educational and behavioral psychology is a dynamic and multi-factor aspect, including, Internet-based learning and instructional and learning theory, media perception and human social interactions, fields of study that apply human behavior to educational technology [4], [5].

However, there is a disambiguation about what ICT as educational technology should refer. Especially for young scientists and education experts do have a limitation to define its paradigm roles in education industry. There is a big public debate that refers to all valid and reliable applied education science, such as equipment, as well as processes and procedures that are derived from scientific research. The gap on understanding of educational technology is visualized as it would be science or materials. In this paper, we proposed a novel idea and approaches that reveal its integral aspects to optimize education performance and facilities in the case of material (the hardware devices and infrastructure) and science (instructional and conceptual contents) of modeling of the human behavior and feelings in the learning process. It means; the educational technology in a given context refers to theoretical, algorithmic or heuristic processes, and physical technology. The contribution of the paper is summarized as it is a novel approach to investigate students' and teachers' technology-related issues, ICT in the learning process and activities and its paradigm impacts on education behavioral and psychological changes.

The paper is organized as Section II is discussed about ICT for the emerging of information society. In Section III, we investigate ICT teaching and learning for the emerging of information society, including collaborative facilities and ICT learning psychological phenomenon. Section IV ICT in behavioral and educational psychology in details dealing with behavioral and cognitive psychology and criticism of constructivism. In Section V, we summarized the paper by highlighting the key discussions and phenomenon, which is followed by the acknowledgements and references. 


\section{ICT FOR THE EMERGING OF INFORMATION SOCIETY}

In the past years, researches on ICT have been investigated how it can influence the education of students, teachers and other communities. Most developing countries such as Uganda, Ethiopia, Kenya and other many African and Asian developing countries have begun to place considerable emphasis on the importance and availability of ICT for education and other sectors dynamically. In this case, China, South Korea and Singapore could be mentioned how ICT made them strong and fast developing countries [6], [7]. The governments are established and endorsed diverse ICT policies as a major driving force of education, economic and socio-cultural developments, which vitally significant to support education in various levels and ways. The educational and behavioral matter of the society is enhanced the learning and employability position prospects. The countries in general, give more emphasis and recognition of the potential role of ICT for their tremendous developmental endeavor and educational facilities and access. Thus, the use of ICT in various fields of society indicates the emergence of the 'information society [3]. The information society is based on the belief that knowledge is the driving force for technology development and also for economic growth and the knowledge works, which provide or from a relatively large proportion of the employment.

ICT for the countries' development and education specifically can do in the provision of media to facilitate communication and learning process. It is the solid foundation of the emerging of the information society entails dramatic changes in production and business activities as a generic term of an integral larger social context. Information society is an agglomeration of both digitized information and electronic networks [6], [8]. The transformation of information society can only be understood if we view it in a broader context where bits, networks and knowledge have a social meaning. To understand the results of technological change, we have to study the social dimension of information society [9]. Rapid development of the information sphere of society is drastically altering the structure of work and employment, and produces new occupations and jobs. More and more people are being drawn into the information society as learners, workers and consumers. People all over the world have high hopes that new technologies will lead to healthier life, greater social freedoms, increased knowledge and more productive livelihoods [10], [11].

\section{ICT TEACHING AND LEARNING FOR THE EMERGING OF INFORMATION SOCIETY}

As the traditional education facilities, its context and flow are a single approach or one flow from the one step such as teachers who had experience and knowledge to learners [12]. Therefore, ICT breaks this and made dynamic that can be diversified, powerful and accessible to most education seekers. It is characterized by a verbal flow of information streaming from the teacher directly to the learners [5]. Whereas, by endorsing ICT as a communication tool and educational facilities, the context and content matter of education are changed, which bring a significant impact on behavioral and educational perception of the society as a whole [8]. In any education process, whether it is traditional or modern, teachers are playing a central role of education process and also to be the source of information. The difference is that for the former (traditional) teachers are the only accelerators or pivoted actors (Fig. 1 a) ), it is one way from teachers to learners. For the later (modern) approach, the process could be facilitated by both teachers and learners as the matter of ICT's facilities, which is a two-way flow of educational and information flow (Fig. 1 b) ).

Therefore, ICTs and information society are concerned with the creation, acquisition, sharing, dissemination, delivery, support and recognition of knowledge, which provides an access to and engaging in the continuous learning that becomes necessary for successful participation in the society development of all social groups of population. It is a critical tool for professional training that learners know how to use ICTs, the easier they can find their way to capture the newest methods towards their specific tasks.

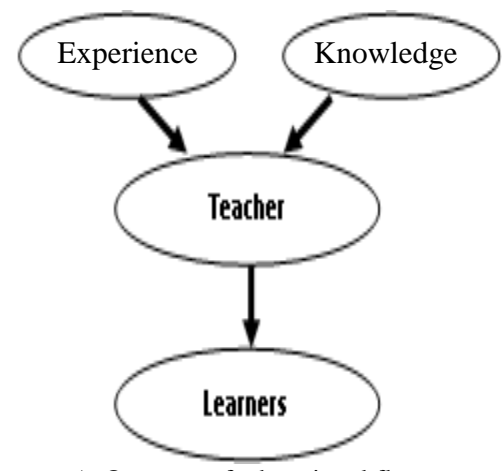

a). One way of educational flow

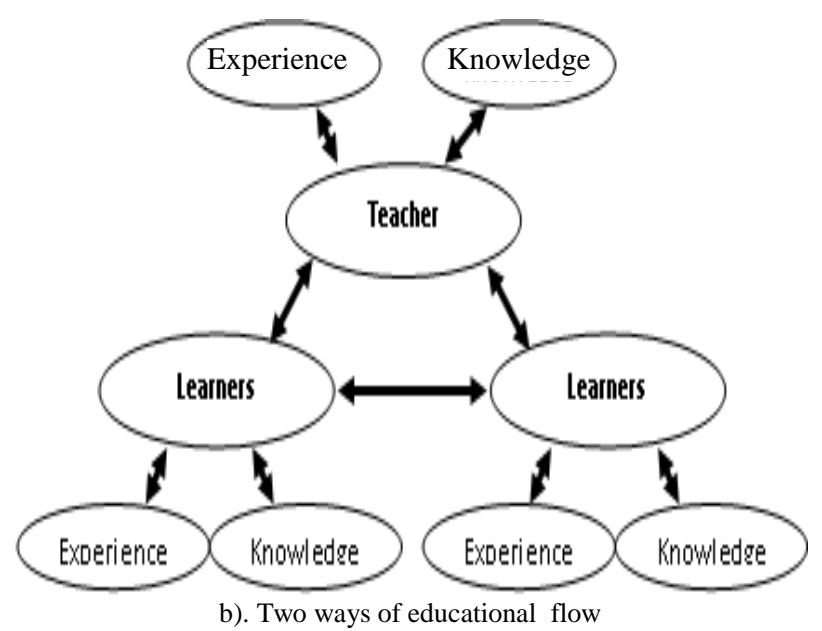

Fig. 1. Education an information flow from pivoted actors to users or learners.

In Fig. 1 a), education is not supported by ICT and teachers are the key to facilitate the learning process. The distributions and access of education are limited. Whereas in Fig. 1 b), the process is supported by ICT and the process is more dynamic, which lead to attain more accessible and distribution of education. Mean that, ICT creates essential situations that both teachers and learners could be important acts as a consultant (teachers) for learners and the Vis versa on implementation and feedback learners for teachers where information can be obtained and communicates knowledge and experience in the societies [11]. This is a technology-based paradigm in which learners make extensive use of ICT to obtain information and experiences. The 
learning responsibilities of the students here are for 'searching', rather than 'receiving' as of fig. 2 .

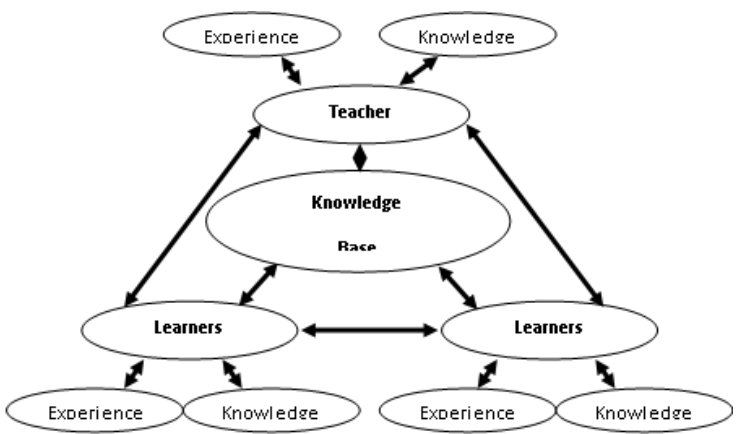

Fig. 2. ICT based learning paradigm.

The impact of ICT on emerging of information society is tremendous, which can be visualized and measured in terms of technological, economic, social and political. ICT as the foundation of information society, it can be evaluated as a dramatic change in production and business activities, culture development, communications in a larger social context. Therefore, information society is not only about digitized information or electronic networks, which can be can be understood in a broader context where bits, networks and knowledge have a social meaning. It is a technological change that the dynamism of the social dimension of information society. Rapid growth of the ICT based information sphere of society is drastically altering the structure of work and employment, and produces new occupations and jobs. For the developing countries, creation of information society is the result of information progress goes together smoothly with various economic and social sectors and businesses. ICT is also becoming the most attractive tool and infrastructure for the younger generation to facilitate the awareness and actual craftsmanship in business for local communities [6]. In order to make this process happen, the traditional education goals should migrate toward gaining locally relevant goals, skills and most important, establishing networks for economic partnerships.

\section{A. ICT and Collaborative Learning Facilities}

ICT is the fundamental technology to educational and behavioral change and e-learning paradigm. ICT is supporting education industry to empower learners' skill capability to interests using the information technology via the Internet [9], [11] For example, Web 2.0 tools and teaching students' facility to use them in the school is vitally important to give access various ways of educational access that they can make choices and create an online presence through content creation [13]. Such technological facilities play tremendous roles on students' educational and behavioral matters that allowing them to create and publish content and also respond to the content creation of others. Created content can be aggregated to show progress and richness and depth of learning and students can respond to the work of others, provide feedback, and learn through their interactions with others online [14]. Not only are students learning, but they are also learning how to be independent learners that gain fineable impacts of the creation of information societies.

For the last few years, in most developing countries have trailed use of ICT, for example, Plasma based educational access in Ethiopia, and wide internet access in Kenya,
Ghana, ... create better educational environments and social software, networked learning activities and practices. These tools and technologies are complimentary and are used concurrently as much of the power of social software is its interoperability. The countries' educational progress move towards web-based collaborative practices and activities has resulted in a change in learning practice. Students have begun using these services for leisure activities and free time, due to their ease of use and breadth of content. Priorities and activities of networked learning and social software are a good fit with countries' education curriculum focus of Personal Learning, and enthusiastic teaching staff is no doubt the key to the acceptance of these technologies and practices [15]. In addition to these, as computers and ICT became more user-friendly, more efficient and cheaper, it awoke interest among educators to pass on theoretical ideas by using ICT in the classroom. Educational technology is thought to serve a dual function: it is a means of thought to provide the tools for the realization of learning as-construction, as well as for the social process of meaning appropriation. It is a basic to offer novel opportunities for novel learning activities and ways of teaching, which, in turn, would require novel psychological insights [16], [17].

As the dynamism and advancement of the technology in the countries and in education industry, specifically by having a focused is and student activity is framed by how it can be shared on the web, and as small elements that students can build on the work of others. Given the breadth of curriculum innovation that has occurred, and the sense of success that has accompanied these changes, education facilities have found renewed energy and excitement to try new ideas and approaches in their use of ICT [18]. For the better of educational and behavioral impacts towards advancing of information society, professional discussions are no longer enough to be bound by a commitment to previous practices and commitments but are focused on increasing student learning outcomes. Moreover, countries are tried to bring change on ICT by endorsing dynamic ICT strategy to the curriculum that has begun implementing an IT based approach to student assessment and knowledge management.

\section{B. ICT and Learning Psychological Phenomenon}

ICT is the corner stone to learning facilities, which bring an enthusiastic behavioural and psychological phenomenon. It is a tool to optimize learning performance and access, a means of communication to address the educational factors, a solid foundation of information societies. Therefore, ICT for education is a technology that potentially useful in any aspects depends on both human and non-human actors, which provide a scientific framework. The technology is playing a paradigm role in which considering many contributions of human and non-human actors, reacting against the idea that characteristics of humans and social organisations distinguish their actions from the inanimate behaviour of technological objects. It offers a socio-technical approach in which neither social nor technical positions are privileged, denying purely social or technical relations is possible. The technology involved in learning facilities, means of communications, strategic development, and future prediction for the better of education paradigms as showed Fig. 3 . 


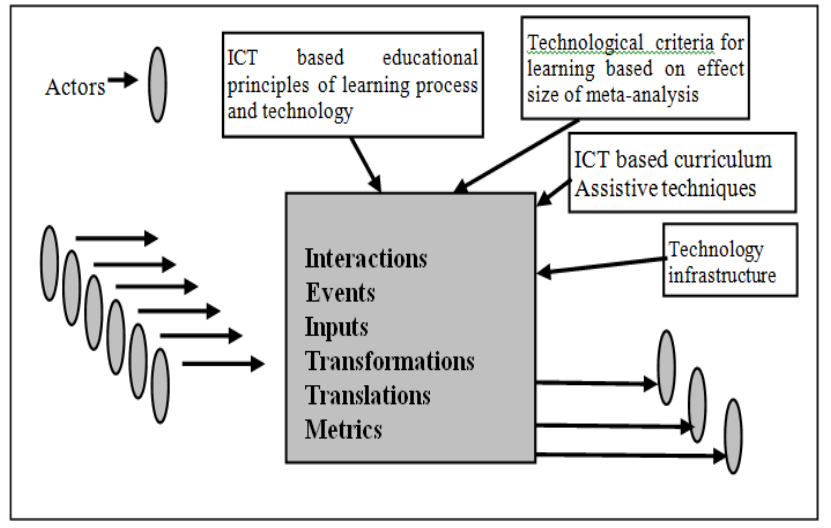

Fig. 3. ICT as the learning phenomenon.

As it is shown on fig.3, ICT for education is the methods of instruction, engagement, thinking processes, technology infrastructure-bandwidth, Internet resources, digital libraries and other facilities. The actors, which include learners, educators ... are seen to contest and negotiate with each other in an attempt to influence the outcome in a direction of their own liking. For example, the education systems and students' parents' interactions and accountability are for the better of learning process that ICT would be a paradigm tool in the education system to optimize modern learning-teaching performances. Mean that ICT will not be an ultimate solution of all educational challenges. That is, ICT technology (both hardware and software) itself acts in the way it was designed, both intentionally and unintentionally, to act the improvement of learning process.

Therefore, ICT needs to be main features in the educational system of the information society, which considering production, dissemination and usage of knowledge based on fundamental skill acquisition, pedagogic and structural innovation in a teaching-learning process. To provide this, countries educational policy must ensure up-to-date pedagogical competence in the information society, integrated and new pedagogic opportunities that can be equal and flexible access to education, and effective and dynamic education structure and organization.

\section{ICT IN BEHAVIORAL AND EDUCATIONAL PSYCHOLOGY}

ICT for education is a key component for its success, learning competency, creativities, support to create and meet complex demands in a particular context skill development in general. The technology implies the mobilization of knowledge, cognitive and practical skills, and social and behavioral components, including attitudes, emotions, values, and motivations. For example, it rolling as the key competence and interactivity in the school, which learners are capable to use education technology interactively that requires an awareness of new ways for individual's creativities and life prosperity, in general [15], [18].

As the countries (developing countries) have made more attention and dynamic strategies on ICT, their social, economic, and technological changes would be made education and training for all more crucial than ever. Because ICT based educational systems are vitally important to different degrees to optimize educational opportunities and roles for students and learners. It provides fundamental knowledge and skills for evolving marketplaces and sophisticated educational and technological environments, and to prepare societies for lifelong learning. To meet these challenges, countries have to focus concurrently on expanding access, improving internal efficiency, promoting the quality of teaching and learning, and improving system management [14], [19]. It is because ICT is an essential tool to gear the educational constructivism plan as the government or specifically school strategy.

ICT based lifelong learning perspective is simply the process of creating computer technology and ICT literacy society. It is the knowledge of renewable supply and to be sustained year to year. Hence, it is a phenomenon of the life wide learning and teaching processes, which involves the different forms of learning during a person's life. It is the integration of ICT in the learning and teaching process that the activities not to be seen as a "finished product." It is two way facilitations and acquiring knowledge as teachers must be prepared to learn the basics of ICT, to incorporate new technology and pedagogical methods to improve their teaching. Educational

\section{A. ICT as the Influence of Behaviorism and Cognitive Psychology}

ICT is the basic for educational learning process and human behavior or cognitive psychology. IT is fundamental in the modern education system as instructional design and communication tools, which clearly visualize and understand what learning is with the belief that learners enable and capable of improve the process. Since, learning exhibits itself as a change in behavior and the inference of learning is made by comparing what behavior is possible before the individual is placed in a "learning situation" and what behavior can be exhibited after such a treatment [20], [21]. The paradigm of ICT for behavioral psychology is therefore, it is information-processing principles and technics as the basis of instructional design. It is the methods to describe educational pedagogy as behavioral changes to develop a human cognitive which linked internal structures to external design of instructional environments [17], [22].

ICT for education in general is a means of identifying learning desires, capabilities, outcomes (intellectual skills, cognitive strategies, verbal information motor skills and attitude) and another methodology to be acquired by individuals. It is a paradigm technology for learning process makes a difference to instruction. The ICT based learning process is a model of education facilities and memory deriving from cognitive psychology and information-processing theory. Therefore, educational and behavioral psychology is the process of learning events that comprise both internal and external conditions of learning process. By internal is essentially previously acquired concepts and skills and the mental processes and structures used by the learner to develop new concepts and skills based on the recall of prior skills. The external is the learning process taking the form of instruction designed for the acquisition of particular learning outcomes.

\section{B. ICT Based Critiques of Educational Instructional Design}

ICT based educational and behavioral instructional design criticism is a systematic approach to advance educational strategies for dealing with incorrect responses of the 
technology towards the learning systems. It is a valid way of drill-and-practice educational computer-based programs that are intended to be used independently of the teacher. It is virtually impossible to substitute the role of the teacher with computer-based activities or designs the teacher into the technology to diagnose incorrect responses and provide opportunities for students to reflect on their learning. For example, NcCarty and Schwandt [23] clearly discussed that the behaviorist rooted pedagogy is accused by constructivists of being authoritarian rather than progressive, teacher-centered as opposed to learner-centered, encouraging passive learning instead of active learning and focusing on transmission teaching rather than discovery learning. It showed that how ICT is essential for semantic educational learning processes [24], [25].

In the past decades, philosophers were having their extreme judgments and also conclusion that derived from their own perceptions. For example, the theorist of instructional design lacks an empirical basis since they relied on the studies designed and conducted within behavioral and cognitive psychology experimental settings. In those experiments, learning components were isolated in order to identify how the human brain functions. The assumption was the learning components could be transferred unproblematically to pedagogic contexts of learning components exist concurrently rather than in isolation. However, as the birth, growth and advancement of ICT based, educational technology or learning methodology is the cumulative process of different actors that brought significant impacts on human behavior and cognitive as the creation of information society. Thus, the structure of educational technology is built upon the rock of science. It means that the extraction of new or valuable methodologies from the existing massive matters [26]-[28].

Furthermore, ICT is a vocabulary consistent with educational technology to the study and ethical practice of facilitating, learning and improving performance by creating, using and managing appropriate technological processes and resources based on the existing facts. It is an instructional technology as the theory and practices of design, development, utilization, management, and evaluation of processes and resources for learning [13], [21]. Educational technology thus refers to the use of ICT (both physical hardware and educational theoretic vis software), which encompasses various domains, including learning theory, computer-based learning process, and other technologies. There are several aspects to describing the technical development of educational technology, including, the theory and practice of educational approaches to learning process, technological tools and media that assist in the communication of knowledge and its development, learning system management, educational subjects, and others [22]. Based on these facts, instructional design can be categorized as behaviorism, cognitivism, and constructivism.

Behaviorism: it is theoretical framework based on experience or animal learning experiments, which leads to learn the human behavior. However, in the modern education system, ICT is a holistic aspect to synthesis the learning process. Mean that the technology of teaching is an attempt to dispel the myths' underlying contemporary education as well as promote the education system based on behavior analysis.
Cognitivism: it is the science underwent significant change based on the empirical framework of behaviorism; cognitive psychology theories look beyond behavior to explain brain-based learning by considering how human memory works to promote learning that is the foundation of a working memory model established as theoretical frameworks. Therefore, ICT has had a major influence on Cognitive Science theory. The Cognitive concepts of working memory and long-term memory have been facilitated by research and technology from the field of Computer Science.

Constructivism: it is a focus on how learners construct their own meaning from new information, as they interact with reality and with other learners who bring different perspectives. ICT as the aspects of constructivism is the process or learning environments requires students to use their prior knowledge and experiences to formulate new, related, and/or adaptive concepts in learning. Under this framework the role of the teacher becomes that of a facilitator, providing guidance so that learners can construct their own knowledge. In this approaches, educators must make sure that the prior learning experiences are appropriate and related to the concepts being taught in which they are utilizing a constructivist perspective may emphasize an active learning environment that incorporates learner centered problem-based, inquiry-based, and project-based learning processes. The novelty of the method is ideally involving real-world scenarios, in which students are actively engaged in critical-thinking activities, as it is shown on Fig. 4.

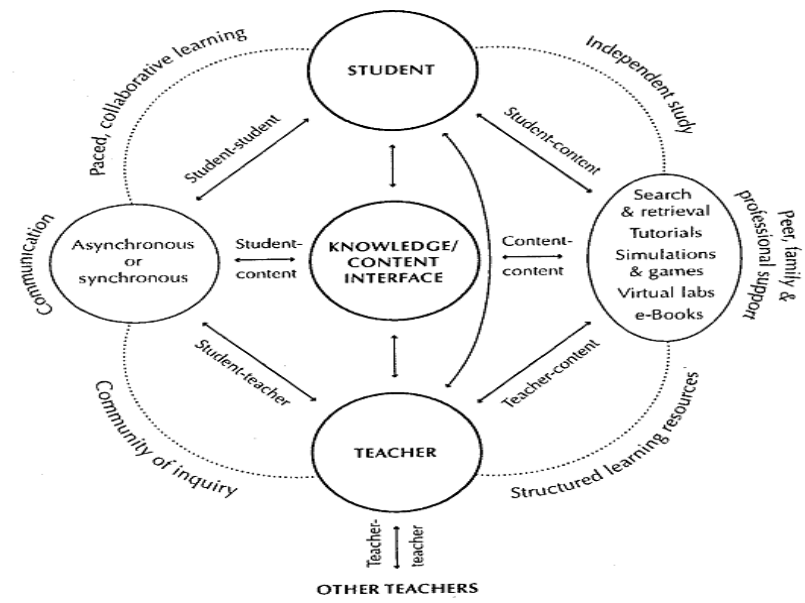

Fig. 4. Technological based instructional design of learning process.

As the paradigm role of ICT, There is a big difference of learning process as the traditional and modern systems. As it is shown on Fig. 4, modern learning system is ICT based constructivism that provides learners would have critical thinking about the situations, make wide for their educational behavior and cognitive and so on. Development on ICT is capital intensive and complex, which need to be systematic and strategic. On the other hand, its outcomes in the school can never be measured clearly by giving exams for students or learners. It should be known that ICTs potentially offer a powerful dimension to transform the way the young generation prepares for further learning. Thus, the main focus as well as the role of ICTs is to act as a catalyst for the learner's interest to get acquainted with the "unknown" as it is characterized in Table I.

The uses of ICT is making major differences in the 
learning of students and teaching approach's shifts. ICT in education plays dynamic roles to a more constructivist learning and an increase in activity and greater responsibility of students. For example, student's ability and thinking gradual progress in using computers changes from learning about computers, to learning computers, and finally to learn with computers. Therefore, ICT based or modern education system is dynamic and analytic learning process based on scientific methods, which leads to moral judgments of pedagogic strategies.

TABLE I: COMPARISON OF TRADITIONAL AND MODERN EDUCATION SYSTEMS

\begin{tabular}{|c|c|}
\hline Traditional systems & $\begin{array}{l}\text { Modern or constructivist } \\
\text { education system }\end{array}$ \\
\hline $\begin{array}{l}\text { Curriculum is presented part } \\
\text { to whole with emphasis on } \\
\text { basic skills }\end{array}$ & $\begin{array}{l}\text { Curriculum is presented whole } \\
\text { to part with emphasis on big } \\
\text { concepts }\end{array}$ \\
\hline $\begin{array}{l}\text { Strict adherence to fixed } \\
\text { curriculum is highly valued }\end{array}$ & $\begin{array}{l}\text { Pursuit of learner questions is } \\
\text { highly valued }\end{array}$ \\
\hline $\begin{array}{l}\text { Curricular activities rely } \\
\text { heavily on textbooks and } \\
\text { workbooks }\end{array}$ & $\begin{array}{l}\text { Curricular activities rely heavily } \\
\text { on primary sources of data and } \\
\text { manipulative materials }\end{array}$ \\
\hline $\begin{array}{l}\text { Students are viewed as } \\
\text { "blank slates" onto which } \\
\text { information is etched by the } \\
\text { teacher }\end{array}$ & $\begin{array}{l}\text { Learners are viewed as thinkers } \\
\text { with emerging theories about } \\
\text { the world }\end{array}$ \\
\hline $\begin{array}{l}\text { Teachers, generally behave } \\
\text { in a didactic manner, } \\
\text { disseminating information to } \\
\text { students }\end{array}$ & $\begin{array}{l}\text { Educators generally behave in } \\
\text { an interactive manner, } \\
\text { mediating the environment with } \\
\text { learners }\end{array}$ \\
\hline $\begin{array}{l}\text { Teachers seek to correct } \\
\text { answer to validate student } \\
\text { learning }\end{array}$ & $\begin{array}{l}\text { Educators seek the learner's } \\
\text { point of view in order to } \\
\text { understand learners present } \\
\text { conceptions for use in } \\
\text { subsequent lessons }\end{array}$ \\
\hline $\begin{array}{l}\text { Assessment of student } \\
\text { learning is viewed as } \\
\text { separate from teaching and } \\
\text { occurs entirely through } \\
\text { testing }\end{array}$ & $\begin{array}{l}\text { Assessment of learning is } \\
\text { interwoven with teaching and } \\
\text { occurs through educator } \\
\text { observations of learners, learner } \\
\text { observation of learners at work } \\
\text { and through learner exhibitions } \\
\text { and portfolios }\end{array}$ \\
\hline $\begin{array}{l}\text { Students primarily work } \\
\text { alone }\end{array}$ & $\begin{array}{l}\text { Learners work primarily in } \\
\text { groups }\end{array}$ \\
\hline
\end{tabular}

\section{CONCLUSION}

ICT is a technological phenomenon of educational and behavioral psychology towards the emerging of information society. It is dynamic, which can be serving as tools of communications and educational instructions' design. Thus, ICT for development and education, specifically vitally important to facilitate jobs, efficient allocation and use of resources. ICT as the context of educational communication, the phenomenon should be developed, applied, and analyzed by all educators, especially to create the instructional communication quality in every lesson. This paper is discussed about the paradigm role of ICT in education industry more emphasizing on learning process. In-depth analyses focused on the effect of ICT as behavioral, cognitive and constructive nature has been discussed in details. The learning process is stimulus packaged in the form of computer-based instruction (CBI). The analysis and verification of learning interaction phenomenon is taking into account the great power of human action and memory that leads the emergence of information society. Moreover, the comparisons between traditional and modern or ICT based constrictive education system has also discussed and presented in the tabulated form.

\section{ACKNOWLEDGMENTS}

Authors are very thanks to the anonymous reviewers for their useful comments, and the works is supported by National Natural Science Foundation (NNSF) of China under Grant 61374135, 61203321, 61203084.

\section{REFERENCE}

[1] T. Anderson, "Toward a theory of online learning," in T. Anderson, and F. Elloumi, Eds., Theory and Practice of Online Learning, Athabasca, Athabasca University, 2004,

[2] A. Subekti, "Effectiveness of learning physics through animation cartoon film, London," University of Indonesia Education, Faculty of Education Department of Educational Technology, 2003,

[3] L. Arienello, "A primer on the brain and nervous system," Brain Facts, Washington, DC: Office On corporate Meadow Design, 2002,

[4] S. Bennet, K. Maton, and L. Kervin, "The 'digital natives', a critical review of the evidence," British Journal of Educational Technology, 2008 ,

[5] G. Conole and M. Dyke et al., "Mapping pedagogy and tools for effective learning design," Computers and Education, vol. 43, pp. 17-33, 2004.

[6] Q. Tang, Transforming Education: The Power of ICT Policies, United Nations Educational, Scientific and Cultural Organization, 2011.

[7] W. J. Pelgrum, "Obstacles to the integration of ICT in education: Results from a worldwide educational assessment," Pergamon, Computers \& Education, vol. 37, pp. 163-178, 2001.

[8] D. Mulyana. Qualitative Research Methods, London. Temaja Rosdakarya. [Online]. Available: http://newhorizons.orgstrategies/accelerated/deporter.htm, 2002,

[9] A. Kadir and C. T. Terra, Introduction to Information Technology, 2003 ,

[10] Jogiyanto, "An integrated approach between basic concepts, technology, application, development and management," Information Technology System, 2003

[11] C. L. Katz and R. Manning, Interpreting, Alexander Sindoro, Sharpening the Brain in Everyday Practice, Batam: Interaksara, 2004

[12] T. R. Craig. (2004). International Communication Association Journal [Online]. Available: http://www.ask/ix

[13] A. Agalianos, R. Noss, and G. Whitty, "Logo in mainstream schools: The struggle over the soul of an educational innovation," British Journal of Sociology of Education, vol. 22, no. 4, pp. 479-500, 2001.

[14] M. Ally, "Foundations of educational theory for online learning," in T. Anderson and F. Elloumi, Eds., Theory and Practice of Online Learning, Athabasca, Athabasca University, 2004.

[15] T. Mayes and S. de Freitas, "Review of e-learning theories, frameworks and models," Jisc e-Learning Models Desk Study, 2004.

[16] D. Meier, "The accelerated learning: New York: Kaifa," Online Journal of Communication and Media Technologies, vol. 2, issue 3, July 2012.

[17] K. Maton, S. Bennet, and L. Kervin. (2007). Digital Natives: Educational Emergency or Moral Panic. [Online]. Available: www.karlmaton.com

[18] A. Ravenscroft, "Designing e-learning Interactions in the 21 st century: Revisiting and rethinking the role of theory," European Journal of Education, vol. 6, no. 2, pp. 133-156, 2001

[19] D. Restendi, "Learning skills fast application processing rate through berasas computer learning tutorial, London," University of Indonesia Education, Faculty of Education, 2003,

[20] N. H. Dedy, "Methods of communication research: Paradigms and empirical social research methodology-classical, London," University of Indonesia, 2003,

[21] D. Darmawan, "Biology of ICT-based communication paradigm," Online Journal of Communication and Media Technologies, vol. 2, issue 3, July 2012.

[22] L. Siragusa and C. Kathryn, "Dixon planned behavior: Student attitudes towards the use of ICT interactions in higher education," in Proc. Ascilite Melbourne, pp. 942-953, 2008.

[23] L. McCarty and T. Schwandt, Seductive Illusions: Von Glaserfeld and Gergen on Epistemology and Education, 2000.

[24] D. Gordon and V. Jeanette, Revolutionary Way of Learning, London: Kaifa, 2003,

[25] M. Dyke et al., "Learning theory and its application to elearning," in G. Connole and M. Oliver, Eds., Contemporary Perspectives in E-Learning Research, Theme, Methods and Impact on Practice, London, Routledge, Taylor and Francis Group, 2007.

[26] I. Abdiilhak and D. Darmawan, Learning in the Communication Model Implementation Group MKBS Lectures in Environmental Sciences 
Faculty of Education UPI, New York: Research Institute for UPI, December 13, 2001.

[27] J. Elen and G. Clarebout, "Instructional design, towards consolidation and validation," Journal of Interactive Educational Media, vol. 3, pp. $1-11,2001$

[28] G. A. Agustian, I Raised ESQ Power Success Secret: A Journey through the Inner AlIhsan, New York: Arga, 2003.

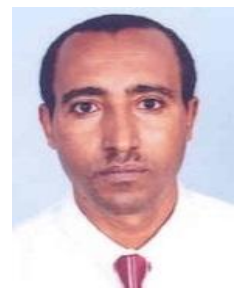

Gebeyehu Belay Gebremeskel is a postdoctoral research fellow in Chongqing University, China. He received his $\mathrm{PhD}$ from Chongqing University, since July 2013, master's Degree from London South Bank University, UK and B. Sc. Degree from Alemaya University, Ethiopia. Dr. Gebeyehu gained solid experience in research and teaching in different positions and institutes. He also engaged and contributed fundamental professional skills in various IT projects and research activities. In his $\mathrm{PhD}$ and master's studying program, he published more than 20 academic papers, which include journals, conference papers, book chapters and other technical reports in his research area and in computing field in general. His research interests include data mining, business intelligence, big data, machine learning, agent technologies, artificial intelligence, data cloud, and others in the field of computer science.

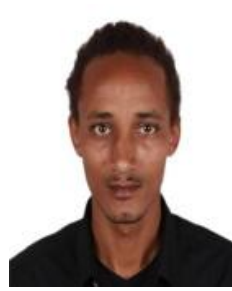

Ayenew Arega Kebede is graduated in educational pedagogue from Bahir Dar University, since July 2006. Currently, he is doing his master's degree in the same field. He is working as a business manager from Mexin PLC in Chongqing, China. Besides his managerial activities, he also is performing many volunteers and professional activities in human rights in relations to women and children right. He also an excellent artist and doing on it on his spare time. His research interest is educational psychology and behavioral, sociology and human rights.

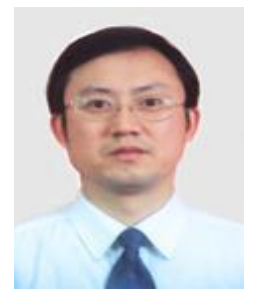

Yi Chai is currently the vice director of College of Automation in Chongqing University. He holds a $\mathrm{PhD}$ degree major in control theory and engineering and master's degree major in industry automation from Chongqing University, and his first degree from National University of Defense Technology major in electronic engineering, China. Professor Chai is a distinguished full professor in Chongqing

University. He is a principal postgraduate courses' lecturer and $\mathrm{PhD}$ tutor, honorable academician and researcher in his field and in the college in general. Because of his deep academic scholastic, he innovated and running more than 40 national projects. Professor Chai is the famous and known academician, and in his successful achievement and patented work, he received more than 9 national awards. He is also a member and head of many professional and technical associations in the national level. He is therefore, highly respectful and honored by his collogues and students because of his immense and exemplary efforts and wishes to deliver applicable and scalable scientific techniques, methodologies, knowledge and experience to his followers. He published many academic and high standard journals, books, and other technical reports in both English and Chinese. His major research directions are in information processing, fusion and control, industrial process control theory and technology, intelligent systems theory and applications, and others in the field of automation. 